\title{
New spasticity from cervical spine pathology in a patient with athetoid cerebral palsy
}

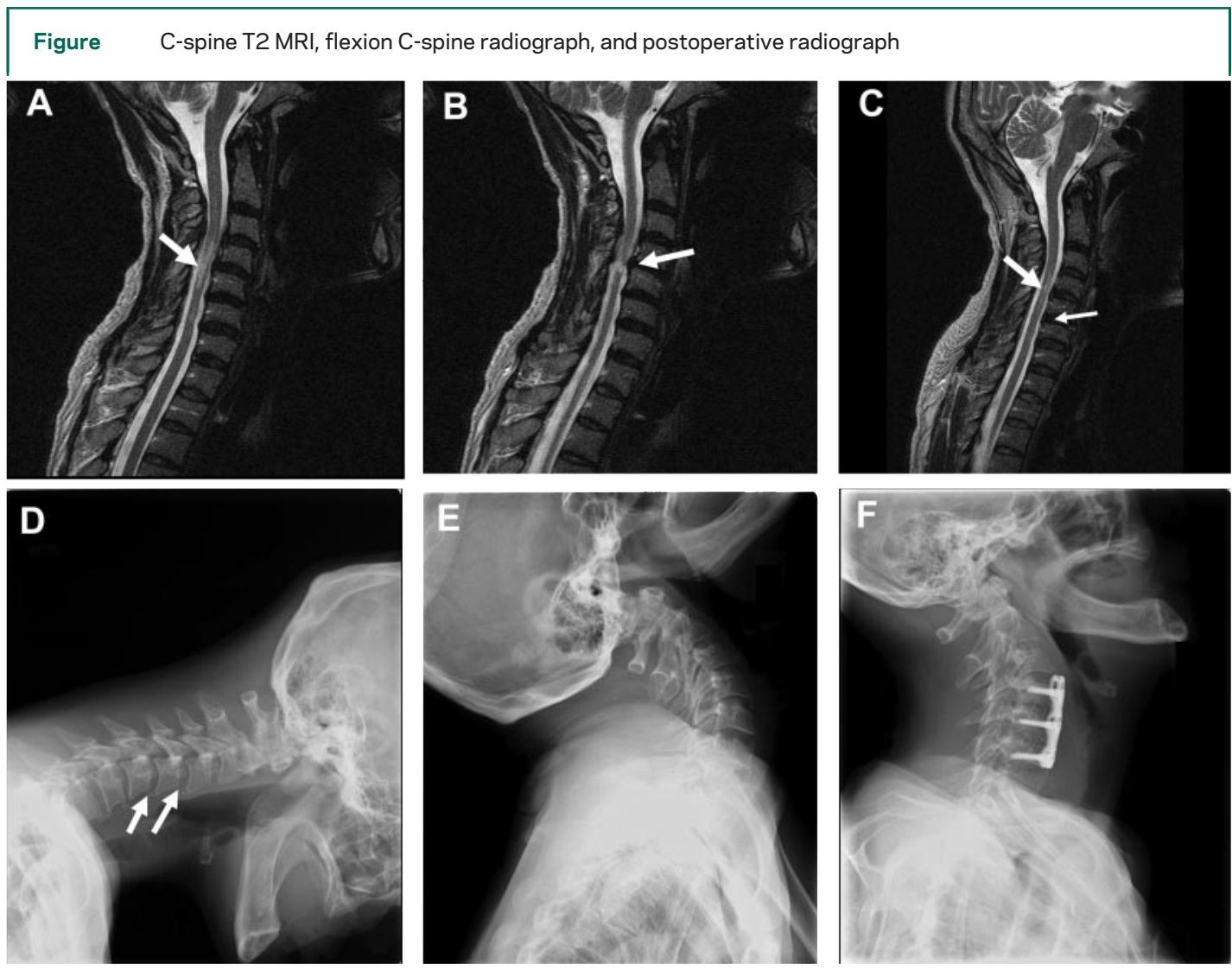

C-spine T2 MRI reveals cord edema (A) and a herniated disc at C4/C5 (B), which are more pronounced in comparison to a study from 3 years earlier (C). Flexion C-spine radiograph demonstrates anterolisthesis at C3/C4 and C4/C5 (D), which disappears in extension (E). Postoperative radiograph demonstrates anatomic alignment (F).

A 47-year-old woman with athetoid cerebral palsy (ACP) experienced isolated right-sided spasticity. Imaging revealed cord edema, a herniated disc, and anterolisthesis (figure, A, B, D). The patient underwent discectomy with spinal fusion (figure, F), and reported improved activities of daily living.

Cervical spine pathology is a well-known complication of ACP caused by repetitive head movements which accelerate degenerative joint disease (DJD), but is often overlooked. It may occur in any movement disorder with repetitive head movements. It includes disc degeneration, predominantly at C5/C6 (a common site in DJD), and listhetic instability. ${ }^{1,2}$ Suspicion for this pathology in patients with ACP may prevent permanent neurologic deficits.

Laura M. Allen, MD, and Mark A. Nigogosyan, MD, La Crosse, WI

Disclosure: The authors report no conflicts of interest.

Address correspondence and reprint requests to Dr. Laura Allen, 2016 Travis Street, La Crosse, WI 54601; lmallen@gundluth.org.

1. Anderson WW, Wise BL, Itabashi HH, Jones M. Cervical spondylosis in patients with athetosis. Neurology 1962;12: 410-412.

2. Harada T, Ebara S, Anwar M, et al. The cervical spine in athetoid cerebral palsy. J Bone Joint Surg 1996; 4:613-619. 


\section{Neurology}

New spasticity from cervical spine pathology in a patient with athetoid cerebral palsy

Laura M. Allen and Mark A. Nigogosyan

Neurology 2008;70;1647

DOI 10.1212/01.wnl.0000310990.25418.fd

This information is current as of April 28, 2008

Updated Information \&

Services

References

Citations

Subspecialty Collections

Permissions \& Licensing

Reprints including high resolution figures, can be found at: http://n.neurology.org/content/70/18/1647.full

This article cites 2 articles, 1 of which you can access for free at: http://n.neurology.org/content/70/18/1647.full\#ref-list-1

This article has been cited by 2 HighWire-hosted articles: http://n.neurology.org/content/70/18/1647.full\#\#otherarticles

This article, along with others on similar topics, appears in the following collection(s):

All Spinal Cord

http://n.neurology.org/cgi/collection/all_spinal_cord

Disc disease

http://n.neurology.org/cgi/collection/disc_disease

Prognosis

http://n.neurology.org/cgi/collection/prognosis

Spastic paraplegia

http://n.neurology.org/cgi/collection/spastic_paraplegia

Spinal cord trauma

http://n.neurology.org/cgi/collection/spinal_cord_trauma

Information about reproducing this article in parts (figures,tables) or in its entirety can be found online at:

http://www.neurology.org/about/about_the_journal\#permissions

Information about ordering reprints can be found online:

http://n.neurology.org/subscribers/advertise

Neurology ${ }^{\circledR}$ is the official journal of the American Academy of Neurology. Published continuously since 1951, it is now a weekly with 48 issues per year. Copyright. All rights reserved. Print ISSN: 0028-3878. Online ISSN: 1526-632X.

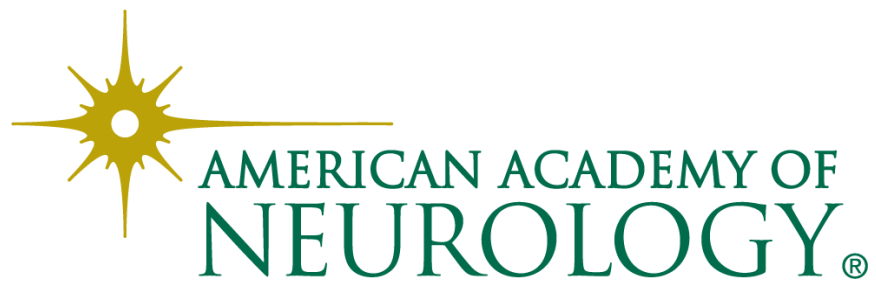

